NASA/TM-2007-214927

(2)

(8)

\title{
Progressive Fracture of Laminated Composite Stiffened Plate
}

Pascalis K. Gotsis

Technological Educational Institute of Serres, Terma Magnisias, Serres

Christos C. Chamis

Glenn Research Center, Cleveland, Ohio

Kostantinos David

Technological Educational Institute of Serres, Terma Magnisias, Serres

Frank Abdi

Alpha STAR Corporation, Long Beach, California 


\section{NASA STI Program . . . in Profile}

Since its founding, NASA has been dedicated to the advancement of aeronautics and space science. The NASA Scientific and Technical Information (STI) program plays a key part in helping NASA maintain this important role.

The NASA STI Program operates under the auspices of the Agency Chief Information Officer. It collects, organizes, provides for archiving, and disseminates NASA's STI. The NASA STI program provides access to the NASA Aeronautics and Space Database and its public interface, the NASA Technical Reports Server, thus providing one of the largest collections of aeronautical and space science STI in the world. Results are published in both non-NASA channels and by NASA in the NASA STI Report Series, which includes the following report types:

- TECHNICAL PUBLICATION. Reports of completed research or a major significant phase of research that present the results of NASA programs and include extensive data or theoretical analysis. Includes compilations of significant scientific and technical data and information deemed to be of continuing reference value. NASA counterpart of peer-reviewed formal professional papers but has less stringent limitations on manuscript length and extent of graphic presentations.

- TECHNICAL MEMORANDUM. Scientific and technical findings that are preliminary or of specialized interest, e.g., quick release reports, working papers, and bibliographies that contain minimal annotation. Does not contain extensive analysis.

- CONTRACTOR REPORT. Scientific and technical findings by NASA-sponsored contractors and grantees.
- CONFERENCE PUBLICATION. Collected papers from scientific and technical conferences, symposia, seminars, or other meetings sponsored or cosponsored by NASA.

- SPECIAL PUBLICATION. Scientific, technical, or historical information from NASA programs, projects, and missions, often concerned with subjects having substantial public interest.

- TECHNICAL TRANSLATION. Englishlanguage translations of foreign scientific and technical material pertinent to NASA's mission.

Specialized services also include creating custom thesauri, building customized databases, organizing and publishing research results.

For more information about the NASA STI program, see the following:

- Access the NASA STI program home page at http://www.sti.nasa.gov

- E-mail your question via the Internet to help@sti.nasa.gov

- Fax your question to the NASA STI Help Desk at 301-621-0134

- Telephone the NASA STI Help Desk at 301-621-0390

- Write to: NASA Center for AeroSpace Information (CASI) 7115 Standard Drive Hanover, MD 21076-1320 
NASA/TM-2007-214927

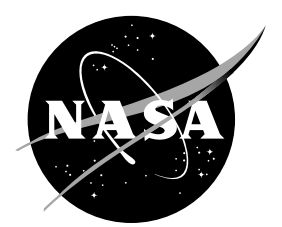

\section{Progressive Fracture of Laminated Composite Stiffened Plate}

PascalisK. Gotsis

Technological Educational Institute of Serres, Terma Magnisias, Serres

Christos C. Chamis

Glenn Research Center, Cleveland, Ohio

Kostantinos David

Technological Educational Institute of Serres, Terma Magnisias, Serres

Frank Abdi

Alpha STAR Corporation, Long Beach, California

National Aeronautics and

Space Administration

Glenn Research Center

Cleveland, Ohio 44135 


\section{Acknowledgments}

The first author would like to thank the Research Committee of Technological Education Institute of Serres, Greece, for funding this research project.

This work was sponsored by the Fundamental Aeronautics Program at the NASA Glenn Research Center.

Level of Review: This material has been technically reviewed by technical management.

Available from

NASA Center for Aerospace Information 7115 Standard Drive

Hanover, MD 21076-1320
National Technical Information Service 5285 Port Royal Road Springfield, VA 22161 


\title{
Progressive Fracture of Laminated Composite Stiffened Plate
}

\author{
Pascalis K. Gotsis \\ Technological Educational Institute of Serres \\ Terma Magnisias, Serres 62120 \\ Christos C. Chamis \\ National Aeronautics and Space Administration \\ Glenn Research Center \\ Cleveland, Ohio 44135 \\ Kostantinos David \\ Technological Educational Institute of Serres \\ Terma Magnisias, Serres 62120 \\ Frank Abdi \\ Alpha STAR Corporation \\ Long Beach, California 90804
}

\begin{abstract}
Laminated fiber-reinforced composite stiffened plate with [0/90/ \pm 45$]$ s plies made of S-Glass/epoxy are evaluated via computational simulation to study damage and fracture progression. The loads are pressure and temperature which varies from 21 to $65.5^{\circ} \mathrm{C}$ (case I) and from 143.3 to $21{ }^{\circ} \mathrm{C}$ (case II). An integrated computer code is used for the simulation of the damage progression. Results show that damage initiation begins at low load level, with matrix cracking at the $0^{\circ}$ (bottom and top) plies, fiber fracture at the bottom $\left(0^{\circ}\right)$ ply and interply delamination at the top $\left(0^{\circ}\right)$ ply. Increasing the applied pressure, the damage growth is expended resulting in fracture through the thickness of the structure. At this stage, 90 percent of the plies damage at applied pressure $15.306 \mathrm{MPa}$ for the case I and 15.036 MPa for the case II. After this stage the cracks propagate rapidly and the structure collapses.
\end{abstract}

\section{Introduction}

The aircraft, marine and automotive industries use stiffened composite plates because of their low weight, high stiffness, and stability. Design considerations with regard to the durability stiffened plates require a priori evaluation of the damage initiation and propagation mechanisms under expected service loads. Concerns of the safety and survivability of critical components require quantifications of the composite structural damage tolerance during overloads. Characteristic flexibilities in the tailoring of composite structures make them more versatile for fulfilling structural design requirements. However, these same design flexibilities render the assessment of composite structural response and durability more complex, prolonging the design and certification process and adding to the cost of the final product. It is difficult to evaluate composite structures because of the complexities in predicting their overall congruity and performance, especially when structural degradation and damage propagation occur. The prediction of damage initiation, damage growth, and propagation to fracture are important in evaluating the loadcarrying capacity, damage tolerance, safety, and reliability of composite structures. Quantification of the structural fracture resistance is also required to evaluate the durability/life of composite structures. The most effective way to obtain this quantification is through integrated computer codes that couple composite mechanics with structural analysis and damage progression models. GENOA computer code used in this study. The code is an updated and improved version of CODSTRAN (Chamis et al., 1996).

The simulation of progressive fracture has been verified to be in reasonable agreement with experimental data from tensile coupon test on graphite/epoxy laminates (Irvin and Ginty, 1986) damage progression in carbon fiber reinforced plastic I-beams (Hang and Minnetyan, 1998) and carbon/carbon 
composite plate specimens subjected to three-point bending (Solinsky et al., 2007). A variety of laminated fiber-reinforced composite structures used to simulate the damage progression and fracture, such as: stiffened adhesively bonded composite structures (Gotsis et al., 1995), damage progression in bolted composite structures (Chamis et al., 1995) and damage tolerance of composite pressurized thin shell structures (Gotsis et al., 1996).

The purpose of this paper is to perform computational simulation to S-Glass/epoxy $(0 / 90 / \pm 45)_{S}$ laminated reinforced-fibers composite stiffened plate, subjected to thermo-mechanical loads, in order to predict the damage progression, fracture thought the thickness and propagation to final fracture (or collapse) of the structure.

\section{Methodology}

The computational simulation is performed by coupling three modules: (1) composite mechanics, (2) finite element analysis, and (3) damage progression tracking. The damage progression module relies on the composite mechanics code ICAN (Murthy and Chamis, 1986) for composite micromechanics, macromechanics and laminate analysis, and calls a finite element analysis module that uses anisotropic thick shell elements to model laminated fiber-reinforced composite structures. The finite element module is based on the mixed finite element method (Nakazawa et al., 1987). By supplying the boundary conditions, the type of analysis desired, the applied loads, and the laminate properties, the module performs the structural analysis. In addition the finite element module provides the computed stress resultants to composite mechanics module, which continuously computes the developed ply stresses for each ply and checks for ply failure.

A computational simulation cycle begins with the definition of constituent properties from a material databank. Composite ply properties are computed by the composite mechanics module. The composite mechanics module also computes through-the-thickness structural properties of each laminate. The finite element analysis module accepts the composite properties that are computed by the composite mechanics module at each node and performs the analysis for a load increment. After an incremental finite element analysis, the computed generalized nodal force resultants and deformations are supplied to the composite mechanics module that evaluates the nature and amount of local damage, if any, in the plies of the composite laminate. Individual ply failure modes are determined using failure criteria associated with a) the negative and positive limits of the six ply stresses components (the in plane stresses $\left(\sigma_{l 11}, \sigma_{l 12}\right.$. $\left.\sigma_{122}\right)$ and the interlaminar stresses $\left.\left(\sigma_{l 33}, \sigma_{l 13}, \sigma_{l 23}\right)\right)$, b) a modified distortion energy (MDE) combined stress failure criterion, and c) interply delamination due to relative rotation of the plies.

The generalized stress-strain relationship for each node is revised according to the composite damage evaluated by the composite mechanics module after each finite element analysis. The model is automatically updated with a new finite element mesh and properties, and the structure is reanalyzed for further deformation and damage. If ply failure criteria indicate new or additional damage during a load increment, the damage tracking module degrades the composite properties affected by the damage and reanalyzes the structure under the same load. When there is no indication of further damage under a load, the structure is considered to be in equilibrium. Subsequently, another load increment is applied leading to possible damage growth, accumulation, or propagation. In the computational simulation cases presented in this paper, analysis is stopped when commencement of the damage propagation phase is indicated by laminate fracture. Laminate fracture is predicted when major principal failure criteria are met for all plies at a node and for all nodes at the structural fracture path until the structure separated into two or more parts.

\section{Laminated Fiber-Reinforced Composite Structure}

The structure used for this investigation is a continuous fiber-reinforced laminated composite stiffened plate (fig. 1). The geometry of the structure has length equal to $254 \mathrm{~mm}(10 \mathrm{in}$.) and width equal 


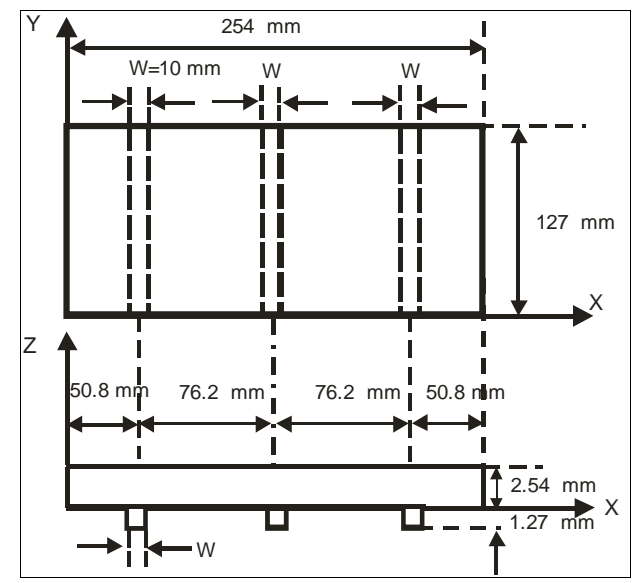

Figure 1.-A laminated fiber-reinforced composite stiffened plate.

to $127 \mathrm{~mm}$ (5 in.). The panel and the stiffened bands are made of the same polymer matrix composite materials S-Glass fiber and high strength (IMHS) epoxy matrix. The S-Glass fiber and epoxy matrix properties are given in tables 1 and 2 . The fiber volume ratio is 0.60 . The laminate configuration is $[0 / 90 / \pm 45]_{\mathrm{s}}$. The skin laminate of the panel consists of eight $0.3175 \mathrm{~mm}(0.0125 \mathrm{in}$. $)$ plies, resulting in a composite thickness of $2.54 \mathrm{~mm}(0.10 \mathrm{in}$.). The stiffened bands well bonded to the bottom surface of the panel, figure 1 . The stiffened band has laminate configuration $[0 / 90 / \pm 45]_{\mathrm{S}}$, with ply thickness equal to $0.1587 \mathrm{~mm}\left(0.00625 \mathrm{in}\right.$.) resulting in a total thickness equal to $1.27 \mathrm{~mm}\left(0.05 \mathrm{in}\right.$.). The $0^{\circ}$ plies are in the $\mathrm{X}$-axis, figure 1 . Regarding the ply numbering convention the first ply lays at the bottom surface of the plate, while the last ply lies at the top surface of the plate. The loads are the pressure normal to the plate, and a uniform temperature, which is increased from the room temperature 21 to $65.5^{\circ} \mathrm{C}$ and remains constant. For comparison reasons another case was examined with the same pressure and the temperature to change from $143.3{ }^{\circ} \mathrm{C}$ to room temperature $\left(2{ }^{\circ} \mathrm{C}\right)$. In the second case residual stresses are taking into account due to the heating and cooling of the fiber composites due to the fabrication process. The boundary conditions are fixed supported.

\section{TABLE 1.-S-GLASS FIBER PROPERTIES}

\begin{tabular}{|c|}
\hline Number of fibers per end \\
\hline 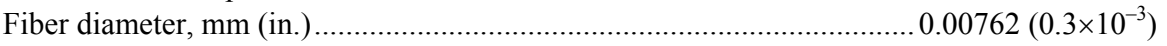 \\
\hline Normal Modulus, GPa (psi) \\
\hline 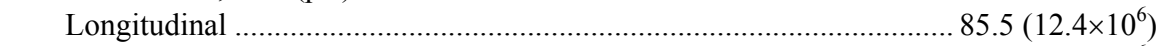 \\
\hline 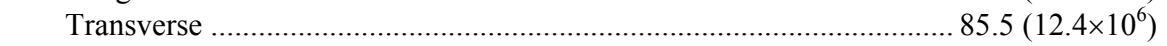 \\
\hline Poisson's ratio \\
\hline$v_{12}$ \\
\hline 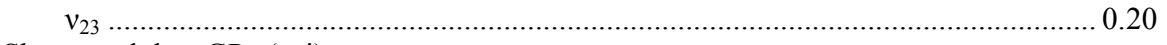 \\
\hline Shear modulus, GPa (psi) \\
\hline $\mathrm{G}_{12}$ \\
\hline $\mathrm{G}_{23}$ \\
\hline Thermal expansion coefficient, $/{ }^{\circ} \mathrm{C}\left(/{ }^{\circ} \mathrm{F}\right)$ \\
\hline 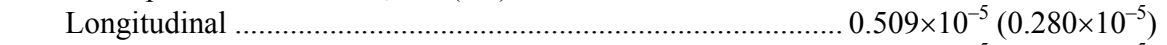 \\
\hline 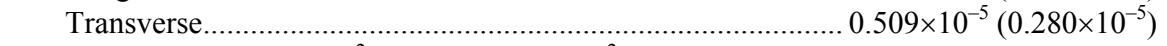 \\
\hline Heat conductivity, J-m $/ \mathrm{hr} / \mathrm{m}^{2} /{ }^{\circ} \mathrm{C}\left(\mathrm{BTU}-\mathrm{in} . / \mathrm{hr} / \mathrm{in} .{ }^{2} /{ }^{\circ} \mathrm{F}\right)$ \\
\hline 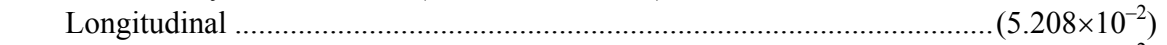 \\
\hline 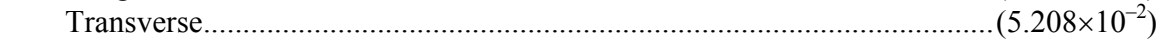 \\
\hline 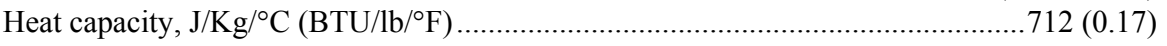 \\
\hline Strength, MPa (ksi) \\
\hline 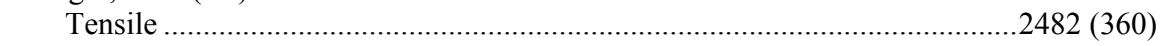 \\
\hline 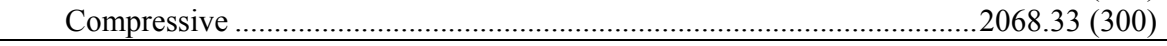 \\
\hline
\end{tabular}




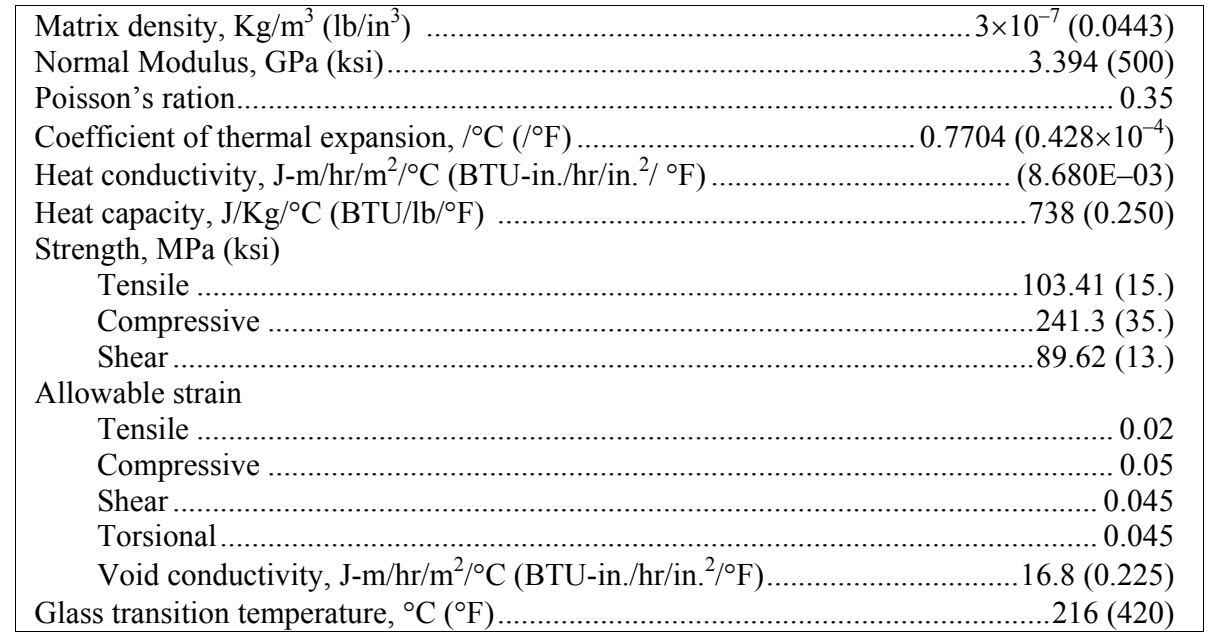

The finite element mesh consists of 396 elements and 442 nodes. Thick shell element was used for the computational simulation.

Damage initiation, growth, accumulation, and propagation to fracture and to structural collapse were monitored as the pressure is gradually increased.

\section{Results and Discussion}

Discussion of the results of the laminated fiber-reinforced composite stiffened plate will follow for the two cases, the case I with the temperature to change from 21 to $65.5^{\circ} \mathrm{C}$, and the case II from 143.3 to $21^{\circ} \mathrm{C}$. The pressure load is increased gradually in both cases.

a) Damage initiation. In case I the damage started at applied pressure $0.55 \mathrm{MPa}(80 \mathrm{psi})$. In the middle stiffener, matrix cracking in tension due to transverse tensile failure mode occurred at the $0^{\circ}$ plies (the bottom and the top), fiber fracture due to the longitudinal compressive failure mode happened at the bottom ply $0^{\circ}$ and delamination due to relative rotation at the top ply $\left(0^{\circ}\right)$. At the panel area, matrix cracking in tension due to transverse tensile failure mode occurred at the $0^{\circ}$ (top) ply.

b) In case II the damage began earlier at $0.275 \mathrm{MPa}$ (40 psi). In the middle stiffener, matrix cracking in tension due to transverse tensile failure mode occurred at the $0^{\circ}$ plies (the bottom and the top), fiber fracture due to the longitudinal compressive failure mode happened at the bottom ply $0^{\circ}$. At the panel area, matrix cracking in tension due to transverse tensile failure mode occurred at the $0^{\circ}$ (top) ply.

c) Damage progression, fracture and structural collapse. In general, overall structural damage may include individual ply damages and through-the-thickness fracture of the composite laminate. The type of the damage growth and the sequence of damage progression depend on the composite structure, loading, material properties, and hygrothermal conditions. A scalar damage variable, derived from the total volume of the composite material affected by the various damage mechanisms, is also evaluated as an indicator of the level of overall damage induced by loading. This scalar damage variable is useful for assessing the overall degradation of a given structure under a prescribe loading condition. The rate of increase in the overall damage during composite degradation may be used as a measure of the structural propensity for fracture. Damage is defined as the volume of the damaged plies divided by the total volume of the structure. Figure 2 presents a comparison of the overall damage progression histories of the stiffened plate for the two loading conditions, and it is plotted the percentage of the damaged plies versus the applied pressure. In case I fracture through the thickness occurred when the percentage of the ply damages was 89.47 percent at applied pressure $15.306 \mathrm{MPa}(2220 \mathrm{psi})$, followed by rapidly damage growth and additional fracture progression resulting in the collapse of the structure, at 25.09 $\mathrm{MPa}$ (3640 psi), at 90.23 percent damage. In case II fracture through the thickness occurred when the percentage of the ply damage was 89.79 percent at 


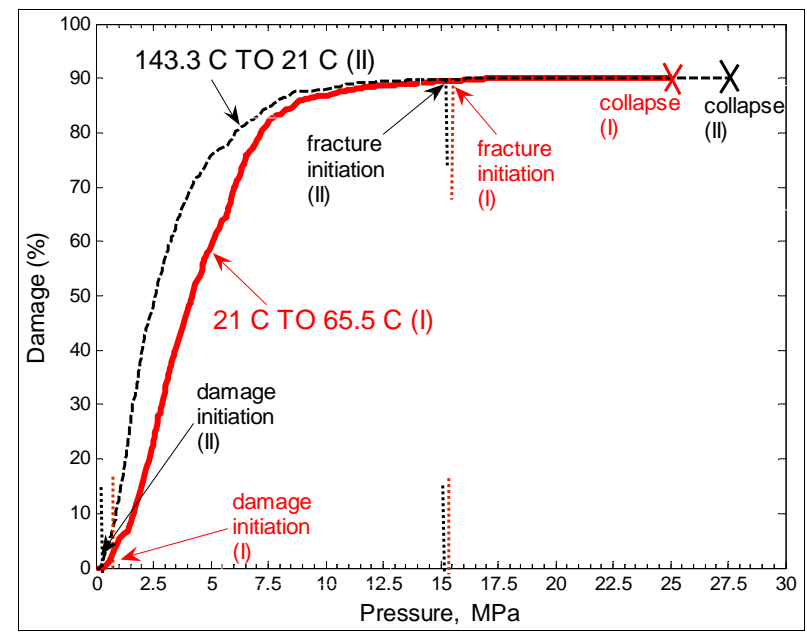

Figure 2.-Damage progression under pressure and temperature S-Glass Epoxy (0/90/45/-45)s stiffened plate.

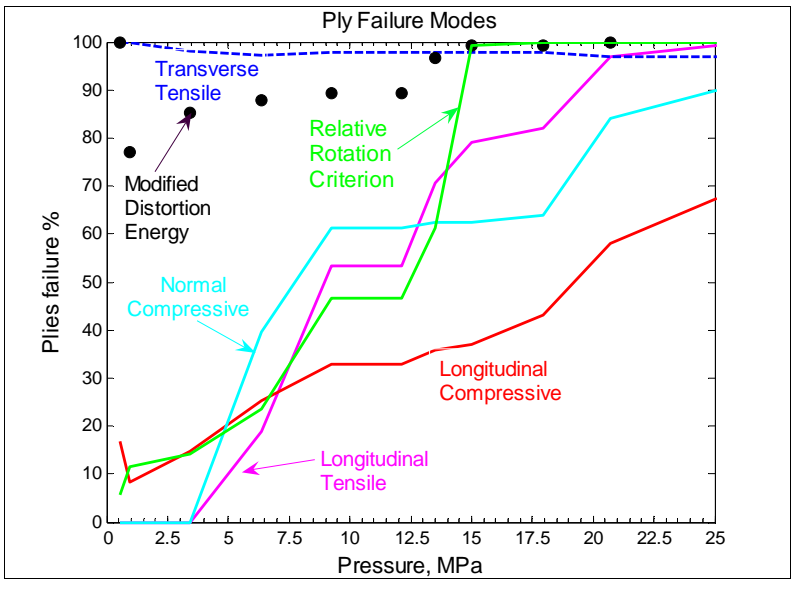

Figure 3.-Dominant failure modes of the S-Glass Epoxy (0/90/45/-45)s stiffened plate under pressure and temperature $\left(21\right.$ to $\left.65.5^{\circ} \mathrm{C}\right)$.

applied pressure $15.03 \mathrm{MPa}(2180 \mathrm{psi})$, figure 2. The collapse of the structure occurred at $27.57 \mathrm{MPa}(4000 \mathrm{psi})$, at 90 percent damage.

d) Ply failure modes. The plies of the laminated composite structure can be damaged by one or more failure modes simultaneously under the effect of the applied load. The various failure modes of the damaged plies of the stiffened plate, versus the applied pressure (case I) are plotted in figure 3 . It is concluded the following:

1) The MDE and the transverse tensile failure modes dominate the other modes. At the fracture initiation $(\mathrm{P}=15.306 \mathrm{MPa})$ almost all damaged plies failed due to matrix cracking in tension, figure 3 .

2) The normal compressive and the longitudinal tensile failure modes are increased gradually and near the fracture initiation increase rapidly up to the collapse. At the fracture initiation, 62 percent of the damaged plies failed due to matrix cracking in compression and 36.9 percent failed due to fiber fracture in tension, figure 3. 


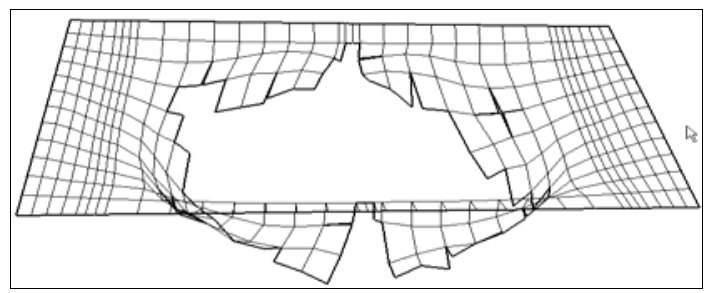

Figure 4.-Fracture progression at $\mathrm{P}=17.65 \mathrm{MPa}$ (2560 psi). Stiffened plate S-Glass Epoxy $(0 / 90 / 45 /-45)_{S}$ with temperature $\left(21\right.$ to $\left.65.5^{\circ} \mathrm{C}\right)$.

3) The relative rotation failure mode begins to increase slowly from the damage initiation $(\mathrm{P}=0.55 \mathrm{MPa})$ state, and speed up close to the fracture initiation, where all damaged plies failed due to interply delamination, figure 3 .

4) The in-plane-shear failure mode increases gradually. At the fracture initiation stage 26 percent of the damaged plies failed and at the collapse of the structure 40.1 percent failed due to the matrix cracking, figure 3 .

5) The transverse normal shear failure mode gradually increases up to the structural collapse. At the fracture initiation stage, 21.5 percent of the damaged plies failed due to the interply delamination. The normal tensile and the transverse compressive failure modes have insignificant effect.

An extensive damage in the structure, at $\mathrm{P}=17.65 \mathrm{MPa}(2560 \mathrm{psi})$, is shown in figure 4 .

\section{Conclusions}

A computational simulation was used to evaluate the structural damage progression response of a SGlass/epoxy $[0 / 90 / \pm 45]_{S}$ laminated fiber-reinforced composite structure under pressure and thermal load (case I and case II). The conclusions follows:

1) Damage initiation began at low load level at $0.55 \mathrm{MPa}$ for the case I and at $0.275 \mathrm{MPa}$ for the case II. In both cases, at the middle stiffener, matrix cracking in tension due to transverse tensile failure mode occurred at the $0^{\circ}$ ply (the bottom and top) and fiber fracture due to longitudinal compressive failure mode happened at the bottom $\left(0^{\circ}\right)$ ply. In the panel area matrix cracking in tension happened at the top ply $\left(0^{\circ}\right)$. In addition interply delamination took place at the top ply $\left(0^{\circ}\right)$ of the middle stiffener in the load case I.

2) Fracture through the thickness began at 90 percent ply damages, due to matrix cracking, fiber breaking and interply delamination. The fracture initiation load for the case I was $15.036 \mathrm{MPa}$ and for the case II $15.03 \mathrm{MPa}$.

3) The fracture initiation followed by a rapidly crack growth resulting in the collapse of the structure. The collapse load for the case I was 25.09 MPa and for the case II 27.57 MPa.

4) The dominant failure mode was the transverse tensile, followed by the normal compressive, longitudinal tensile and the relative rotation. The in-plane shear failure mode had moderate effect.

\section{References}

Chamis C.C., Murthy P.L.N., Minnetyan L., "Progressive Fracture of Polymer Matrix Composite Structures," Theoretical and Applied Fracture Mechanics vol. 25, 1996, pp. 1-15.

Chamis C.C., Gotsis P.K., Minnetyan L., "Damage Progression in Bolted Composite Structures," Proceedings of the USAF Structural Integrity Program Conference, 1995.

Gotsis P.K., Chamis C.C., Minnetyan L., "Effect of Combined Loads in the Durability of a Stiffened Adhesively Bonded Composite Structure," Proceedings of the 36th AIAA/ASME/ASCE/AHS/ ASC Structures, Structural Dynamics, and Material Conference, AIAA-95-1283-CP, part.2, 1995, pp. 1083-1092. 
Gotsis P.K., C.C. Chamis, and L. Minnetyan, "Progressive Fracture of Fiber Composite Shell Structures Under Internal Pressure and Axial Loads," NASA TM-07234, 1996.

Huang D., L. Minnetyan, "Damage Progression in Carbon-Fiber Reinforced I-beams," ASCE Journal of Composites for Construction vol.2, 1998, pp. 38-45.

Irvin F.B., Ginty C.A., "Progressive Fracture of Fiber Composites," Journal of Composite Materials, vol. 20, 1986, pp. 166-184.

Murthy P.L.N., Chamis C.C., "Integrated Composite Analyzer (ICAN): Users and Programmers Manual," NASA Technical Paper 2515, 1986.

Nakazawa S., Dias J.B., Spiegel M.S., "MHOST Users's Manual," Prepared for NASA Lewis Research Center by MARC Analysis Research Corp., 1987.

Sokolinsky V.S. et al., "Failure analysis of Space Shuttle reinforced carbon-carbon Plates," International Journal of Computers \& Structures, 2007, in the press. 


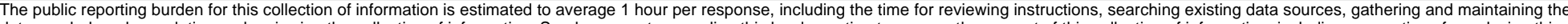

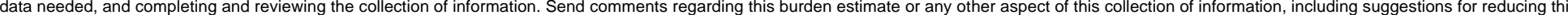

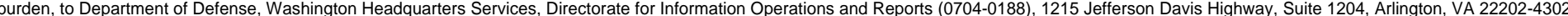

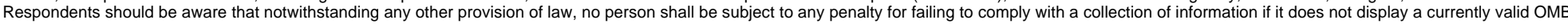
control number.

PLEASE DO NOT RETURN YOUR FORM TO THE ABOVE ADDRESS.

\section{REPORT DATE (DD-MM- $Y Y Y Y)$ \\ 2. REPORT TYPE \\ 3. DATES COVERED (From - To)}

01-08-2007

\section{TITLE AND SUBTITLE}

Technical Memorandum

Progressive Fracture of Laminated Composite Stiffened Plate

5b. GRANT NUMBER

5c. PROGRAM ELEMENT NUMBER

6. AUTHOR(S)

Gotsis, Pascalis, K.; Chamis, Christos, C.; David, Kostantinos; Abodi, Frank

\section{5d. PROJECT NUMBER}

5e. TASK NUMBER

5f. WORK UNIT NUMBER

WBS 561.581.02.08.03.15.03

\section{PERFORMING ORGANIZATION} REPORT NUMBER

E-15816

National Aeronautics and Space Administration

John H. Glenn Research Center at Lewis Field

Cleveland, Ohio 44135-3191

\section{SPONSORING/MONITORING AGENCY NAME(S) AND ADDRESS(ES)}

National Aeronautics and Space Administration

Washington, DC 20546-0001

\section{SPONSORING/MONITORS ACRONYM(S) \\ NASA}

11. SPONSORING/MONITORING REPORT NUMBER

NASA/TM-2007-214927

\section{DISTRIBUTION/AVAILABILITY STATEMENT}

Unclassified-Unlimited

Subject Categories: 39 and 24

Available electronically at http://gltrs.grc.nasa.gov

This publication is available from the NASA Center for AeroSpace Information, 301-621-0390

\section{SUPPLEMENTARY NOTES}

\section{ABSTRACT}

Laminated fiber-reinforced composite stiffened plate with [0/90/ \pm 45$]$ s plies made of S-Glass/epoxy are evaluated via computational simulation to study damage and fracture progression. The loads are pressure and temperature which varies from 21 to $65.5^{\circ} \mathrm{C}$ (case I) and from 143.3 to $21^{\circ} \mathrm{C}$ (case II). An integrated computer code is used for the simulation of the damage progression. Results show that damage initiation begins at low load level, with matrix cracking at the $0^{\circ}$ (bottom and top) plies, fiber fracture at the bottom $\left(0^{\circ}\right)$ ply and interply delamination at the top $\left(0^{\circ}\right)$ ply. Increasing the applied pressure, the damage growth is expended resulting in fracture through the thickness of the structure. At this stage, 90 percent of the plies damage at applied pressure $15.306 \mathrm{MPa}$ for the case I and $15.036 \mathrm{MPa}$ for the case II. After this stage the cracks propagate rapidly and the structure collapses.

\section{SUBJECT TERMS}

Fiber reinforcement; Polymer matrix; Plates fracture

\begin{tabular}{|c|c|c|c|}
\hline \multicolumn{3}{|c|}{ 16. SECURITY CLASSIFICATION OF: } & \multirow{2}{*}{$\begin{array}{l}\text { 17. LIMITATION OF } \\
\text { ABSTRACT }\end{array}$} \\
\hline $\begin{array}{l}\text { a. REPORT } \\
\text { U }\end{array}$ & $\begin{array}{l}\text { b. ABSTRACT } \\
\text { U }\end{array}$ & $\begin{array}{l}\text { c. THIS } \\
\text { PAGE } \\
\text { U }\end{array}$ & \\
\hline
\end{tabular}

18. NUMBER
OF
PAGES
13

19a. NAME OF RESPONSIBLE PERSON
Christos C. Chamis
19b. TELEPHONE NUMBER (include area code)
216-433-3252

Standard Form 298 (Rev. 8-98) Prescribed by ANSI Std. Z39-18 

